https://doi.org/10.17816/MAJ191S136-37

\title{
AUTONOMIC NERVOUS REGULATION OF HEART RATE AND BIOELECTRIC BRAIN ACTIVITY AT THE HEART RATE VARIABILITY BIOFEEDBACK IN HUMANS DEPENDING FROM THE INITIAL SERUM TNF- $\alpha$ LEVEL
}

\author{
L.V. Poskotinova, D.B. Demin, E.V. Krivonogova, O.A. Stavinskaya, S.N. Balashova
}

N. Laverov Federal Center for Integrated Arctic Research, RAS, Arkhangelsk, Russia

\section{ВЕГЕТАТИВНАЯ РЕГУЛЯЦИЯ СЕРДЕЧНОГО РИТМА И БИОЭЛЕКТРИЧЕСКАЯ АКТИВНОСТЬ ГОЛОВНОГО МОЗГА ПРИ БИОУПРАВЛЕНИИ ВАРИАБЕЛЬНОСТЬЮ СЕРДЕЧНОГО РИТМА У ЧЕЛОВЕКА В ЗАВИСИМОСТИ ОТ СОДЕРЖАНИЯ В КРОВИ ФАКТОРА НЕКРОЗА ОПУХОЛИ-АЛЬФА}

\author{
Л.В. Поскотинова, Д.Б. Дёмин, Е.В. Кривоногова, О.А. Ставинская, С.Н. Балашова
}

ФГБУН «Федеральный исследовательский центр комплексного изучения Арктики им. акад. Н.П. Лаверова» РАН, Архангельск

liliya200572@mail.ru

The aim of this study was to determine the amplitude-frequency characteristics of the electroencephalogram (EEG) and heart rate variability (HRV) in humans, depending on the initial serum TNF- $\alpha$ level at a single session of heart rate variability biofeedback (HRV BF) due to increase the total power of the HRV spectrum. Among hypertensive individuals (blood pressure 140-160/80-100 mm Hg) subgroups with an optimal serum TNF- $\alpha$ level (below than 75 quartile $-84,4 \mathrm{pg} / \mathrm{ml}$ ) and with a high serum TNF- $\alpha$ level (more than $84,4 \mathrm{pg} / \mathrm{ml}$ ) were selected. In individuals with an optimal serum level of TNF- $\alpha$, an increase in the total HRV spectral power, a decrease in the stress index, systolic blood pressure and a decrease in the EEG power in the theta range in the frontal brain regions after HRV BF session were identified. In individuals with a high serum TNF- $\alpha$ level the effectiveness of HRV BF was minimal against the background of continuing sympathicotonia and high theta EEG-activity.

Keywords: tumor necrosis factor alpha.

Цель исследования - определение характеристик электроэнцефалограммы (ЭЭГ), вариабельности сердечного ритма (ВСР) и артериального давления (АД) у людей в зависимости от фонового содержания ФНО- $\alpha$ в сыворотке крови после однократного сеанса биоуправления с целью увеличения общей мощности спектра ВСР. Среди лиц с АД 140-160/80-100 мм рт. ст. (признаки артериальной гипертензии) выделены подгруппы с оптимальным уровнем ФНО- $\alpha$ в сыворотке крови (менее 75-го перцентиля - 84,4 пг/мл) и с высоким содержанием (более 84,4 пг/мл). У лиц с оптимальным уровнем ФНО- $\alpha$ после сеанса биоуправления происходило значимое повышение общей мощности ВСР, снижение стресс-индекса, систолического АД и мощности ЭЭГ в тета-диапазоне в лобных отделах мозга. У лиц с повышенным уровнем ФНО- $\alpha$ эффективность биоуправления параметрами ВСР была минимальная на фоне сохраняющейся симпатикотонии и высокой тета-активности ЭЭГ.

Ключевые слова: фактор некроза опухоли альфа.

Introduction. Heart rate variability biofeedback (HRV BF) promotes activation of baroreflex activity [1] and is reflected on the restructuring of brain activity patterns even for a single session of HRV BF [2]. High levels of tumor necrosis factor alpha (TNF- $\alpha$ ) are associated with the development of cognitive disorders. There is reason to consider that the effectiveness of cortical-visceral communications and the success of biofeedback training as a type of cognitive activity will also depend on the activity of inflammatory processes in the human organism. The aim of this study was to determine the amplitude-frequency characteristics of the electroencephalogram (EEG), heart rate variability (HRV) and blood pressure (BP) in humans, depending on the initial serum TNF- $\alpha$ level after a single HRV BF session due to increase the total spectral power of HRV.
Material and methods. In accordance with the ethical principles of the WMA Declaration of Helsinki, 76 people aged 30-53 years in Arkhangelsk were examined, including 33 healthy people with BP less than 140/90 $\mathrm{mm} \mathrm{Hg}$; 43 people with BP 140-160/80-100 mm Hg (hypertensive persons). After blood sampling from the ulnar vein for the subsequent determination of serum TNF- $\alpha$ levels in the examined individuals, EEG, HRV and BP were recorded in a sitting position. HRV using the «Varicard» equipment (Ramen, Russia) was recorded before, during a single HRV BF session in order to enhance the total spectral power (TP, $\left.\mathrm{mc}^{2}\right)$ and after the HRV BF session (5 minutes each stage). The absolute EEG spectral power $\left(\mathrm{mcV}^{2}\right)$ was recorded using the "Encephalan" equipment (Medicom, Russia) before, during and after the 
HRV BF session with monopolar scheme in 16 standard EEG leads using the 10-20 system with open eyes; artifact-free records were used. Subsequently, serum TNF- $\alpha$ levels were performed by ELISA (Bender Medsystem, Austria) using the "Multiskan" analyzer (Finland) in the laboratory of regulatory mechanisms of immunity (research supervisor prof. Dobrodeeva L.K.). Statistical data processing was performed using software Statistica 10.0.

Results. The serum levels of TNF- $\alpha$ were not statistically dependent on the level of blood pressure in the groups; the median was $69.70 \mathrm{pg} / \mathrm{ml}$, and the interquartile range $25 \% ; 75 \%$ was $(62.52 ; 84.40) \mathrm{pg} / \mathrm{ml}$. In persons with blood pressure less than $140 / 90 \mathrm{~mm}$ $\mathrm{Hg}$ were not detected statistically significant correlation of TNF-alpha and EEG, HRV parameters during HRV BF session; in hypertensive individuals such correlations were occurred $(r$ Spearmen $=0.35-0.41, p<0.05-0.01)$. Among hypertensive individuals, subgroups with an optimal serum TNF- $\alpha$ level (below than $75 \%$ quartile $84.4 \mathrm{pg} / \mathrm{ml}$ ) and with a high serum TNF- $\alpha$ level (more than $84.4 \mathrm{pg} / \mathrm{ml}$ ) were selected. In individuals with optimal serum levels TNF- $\alpha$ after a HRV BF session a significant increase in total spectral power of HRV $(p<0.05)$, a decrease in the stress index $(p<0.05)$, decrease in systolic blood pressure $(p<0.05)$ were identified. Also, individuals with an optimal serum TNF- $\alpha$ level had a significant decrease in theta-EEG spectral power $(p<0.05)$ in the frontal brain areas. In individuals with high serum TNF- $\alpha$ level HRV BF session was unsuccessful, i.e. there were no significant changes in total spectral power of HRV, stress index and systolic blood pressure $(p>0.05)$. The background values of the EEG theta activity in these persons were quite high, including due to frequent paroxysmal EEG-phenomena in the frontal brain regions, indicating a high activity of the diencephalic structures. There was no significant decrease in EEG theta activity during HRV BF session $(p>0.05)$.

Thus, in individuals with high serum TNF- $\alpha$ levels the effectiveness of the HRV BF was minimal against the background of continuing sympathicotonia and high activity of the brain diencephalic structures. Our data are consistent with the information that the development of cognitive-behavioral strategies in overcoming emotional stress is better realized in peoples with lower levels of TNF- $\alpha$ in peripheral blood [3].

Acknowledge. The work was performed according to the fundamental research work of N. Laverov Federal Center for Integrated Arctic Research, RAS (No. of state registration 115050610141).

\section{References}

1. Vaschillo EG, Vaschillo B, Lehrer PM. Characteristics of resonance in heart rate variability stimulated by biofeedback. Applied Psychophysiology Biofeedback. 2006;31(2):129-142.

2. Demin DB, Poskotinova LV. Changes in the spectral characteristics of the electroencephalogram during biocontrol of heart rate variability parameters in healthy subjects. Neuroscience and Behavioral Physiology. 2018;48(8):913-916.

3. Master SL, Amodio DM, Stanton AL, et al. Neurobiological correlates of coping through emotional approach. Brain Behavior and Immunity. 2009;23(1):27-35. 